\title{
Spring wheat mixtures in northern crop production: ability of mixtures to buffer disease development and yield loss caused by Septoria nodorum
}

\author{
REIJO KARJALAINEN \\ Departments of Plant Pathology and Plant Breeding \\ University of Helsinki, SF-00710 HELSINKI, Finland
}

\begin{abstract}
Epidemic development of Septoria nodorum was studied in pure stands and mixtures of two spring wheat cultivars Tähti (susceptible) and Kadett (moderately resistant) in 1983-1985. Apparent infection rates in the mixture were similar to that of the more resistant pure stand. In all three years, disease levels in mixed stands were lower than the arithmetic mean of the pure stands.

The yield experiments indicated that under low or moderate disease stress mixtures can buffer yield reduction effectively. However, when disease levels were high, mixtures appeared to be less effective in that respect. The results are discussed in relation to possible mechanisms of intraspecific mixtures to retard non-specialized pathogens. The use of wheat mixtures to prevent disease induced yield losses caused by $S$. nodorum is also discussed.
\end{abstract}

Index words: spring wheat, cultivar mixtures, yield stability, disease resistance, Septoria nodorum

\section{Introduction}

Considerable theoretical and practical interest has been focused in recent years on the evaluation of genotypic mixtures in cereal crop production, and there is some evidence to support the idea that mixtures have several advantages over monocultures, such as greater stability of performance across diverse environments (JENSEN 1952, SiMMONDS 1962, TrenBath 1974) and more diverse and stable resistance to diseases (JENSEN 1952, BORLAUG 1958, Suneson 1960, Browning and Frey 1969). The reason why mixtures seem to be advantageous over monocultures lies in the in- teraction between genotype and environment for each cultivar (WoLFE and BARRETT 1980, Rajeswara Rao and Prasad 1984). It is known (Wolfe and BARRETT 1980) that the way each cultivar responds to the range of environments may be unique to that particular cultivar, and in many cases such differences are extremely difficult to measure and predict. It has been suggested (MARSHALL and BrowN 1973) that even in the absence of intergenotypic interactions, a mixture would be more stable than its components, provided at least one component line responds differentially to at least one environment. Extensive data of oat mixtures and multilines (JENSEN 1952, 
Pfahler and Linskens 1979, Shorter and FREY 1979) indicate that genotype - environment interaction variances for grain yields of mixtures are often smaller than those for oat lines and cultivars grown in monoculture. The better utilization of environmental resources such as water, light, and nutrients under suboptimal conditions (Frey and Maldonado 1967, Rajeswara Rao and Prasad 1982) might partly account for the yield advantage of mixtures over monocultures. Consequently, the better ability to compensate yield losses in a stress environment is likely to provide stable performance compared to pure stands. However, Clay and Allard (1969) have shown that in some cases barley mixtures can be less stable than monocultures.

It is well demonstrated (ADAMS et al. 1971, DAY 1973, MARSHALl 1977) that the increased uniformity of modern crop production has sometimes caused unpredictably serious crop losses due to disease epidemics. Particularly in modern cereal production the widespread use of one or a few similar and genetically homogeneous cultivars provides ideal conditions for the rapid spread of virulent isolates of foliar pathogens. Therefore, the introduction of single major resistance genes into commercial cultivars and the cultivation of the varieties without exact knowledge of the virulence data of the pathogen population has often led to the breakdown of resistance to biotrophic fungi of cereals. It was suggested by Jensen (1952) and Borlaug (1958) that difficult cereal pathogens can be controlled by mixing cultivars of different resistances.

Extensive data of recent studies of biotrophic pathogens of oats (FrEY et al. 1977), wheat (FrIED et al. 1979), and barley (WoLFE and BARRETT 1982) indicate that disease progress in mixtures is much less than the mean of component pure stands. In addition, long practical evidence of growing oat multilines (BRownING et al. 1979) also indicates that multilines can effectively buffer against the yield reduction caused by crown rust epidemics.

However, very little is known of how mix- tures affect the disease progress of pathogens not specialized to cultivars. Recently, JEGER et al. (1981 a) proposed theoretical models suggesting that in many circumstances the amount of unspecialized pathogens in mixtures will be equal to or less than the arithmetic mean of component pure stands. So far, experimental evidence (JEGER et al. 1981 b) is too limited to verify the predictive ability of this model.

Septoria nodorum Berk. is an important and widespread pathogen of wheat and barley (KING et al. 1983), and it is capable of causing yield reduction even at a moderate level of infection (OBST 1977). In the last years $S$. nodorum has caused significant yield reductions to Finnish wheat crops (KARJALAINEN et al. 1983). The cheapest and economically most feasible method of controlling the disease caused by $S$. nodorum is to use resistant cultivars. However, recent studies (KARJALAINEN 1984, 1985) have indicated that all Finnish cultivars are susceptible to the disease. Therefore, the question arises whether cultivar mixtures can be used to reduce disease progress and the yield losses caused by $S$. nodorum. The purpose of the present study was to evaluate the idea proposed by JEGER et al. (1981 a, b) that cultivar mixtures can reduce the amount of unspecialized disease in mixtures compared with the mean of the pure components. The present study was carried out in 1983-1985 using mixtures of susceptible Finnish cv. Tähti and moderately resistant Swedish cv. Kadett.

\section{Materials and methods}

The data presented in this study are based on trials carried out at the experimental farm of the University of Helsinki in the years 1983-1985. Two spring wheat cultivars differing in their resistance to Septoria nodorum were selected for the study. Tähti, a late Finnish variety has been cultivated in southern Finland for several years mainly because of its good baking quality, stiff straw and resistance to sprouting damage. Recent cultivar trials 
(Karjalainen et al. 1983, Karjalainen 1984) have shown that Tähti is very susceptible to $S$. nodorum, which has caused serious crop losses in the last, rainy years (KARJALAINEN 1985), and the popularity of Tähti has been dramatically reduced. Instead, a high-yielding Swedish spring wheat cultivar Kadett has become popular in southern Finland. Kadett is moderately resistant to $S$. nodorum and clearly outyields Tähti.

The experiment was laid out in a randomized block design with eight replications in 1983, six in 1984, and eight in 1985. Plot size was $10 \mathrm{~m}^{2}$. Pure stands and their binary mixtures (1983 and 1984) as well as more complicated mixtures, Tähti $30 \% /$ Kadett $70 \%$, Tähti $50 \% /$ Kadett $50 \%$, and Tähti $70 \%$ / Kadett $30 \%$ (1985), were used.

Half of the experimental plots were artificially inoculated with $S$. nodorum and separated by oat plots in order to prevent inoculum from spreading into controls. Inoculum was applied onto the plants by spraying $\left(10^{6} \mathrm{co}-\right.$ nidia $/ \mathrm{ml}$ ) twice, starting at the four leaf stage. The preparation of inoculum has been previously described by KARJALAINEN et al. (1983).

Disease assessment based on estimating the percentage area covered by lesions on flag and second leaves. Two assessments were made in 1983 and 1985, four in 1984. The data on disease severity are based on the measurement of

Table 1. Monthly mean temperatures and total rainfall in May-August 1983-1985 at HelsinkiMalmi airport.

\begin{tabular}{llcr}
\hline & & $\begin{array}{c}\text { Mean } \\
\text { temperature } \\
{ }^{\circ} \mathrm{C}\end{array}$ & $\begin{array}{c}\text { Rainfall } \\
\mathrm{mm}\end{array}$ \\
\hline 1983 & May & 11.8 & \\
\hline & June & 13.9 & 37.5 \\
& July & 18.3 & 55.3 \\
& August & 15.8 & 23.8 \\
1984 & May & 12.9 & 52.4 \\
& June & 14.4 & 43.5 \\
& July & 15.6 & 55.2 \\
& August & 15.5 & 155.2 \\
& May & 9.4 & 29.9 \\
& June & 13.7 & 60.5 \\
& July & 16.1 & 66.3 \\
August & 16.3 & 77.5 \\
\hline
\end{tabular}

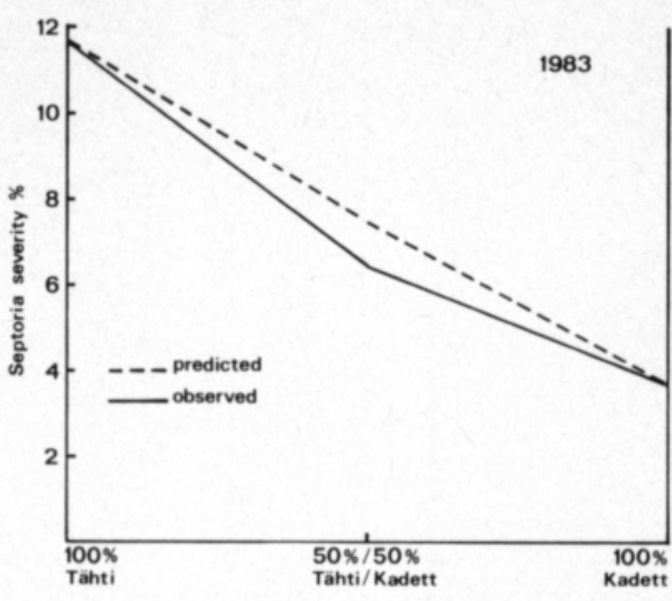

Fig. 1. Disease severity of S. nodorum (average of two upper leaves) of spring wheat cultivars Tähti and Kadett and their binary mixture based on the average of two disease observations in 1983. The percentage diseased leaf area values were transformed using the arc-sin transformation.

60 tillers per plot. Data comparisons between yield and 1000-grain weight were made in relation to uninoculated control plots. The percentage of diseased leaf area was transformed using the arc-sin transformation.

\section{Results}

\section{Effects of mixtures on disease progress}

Disease progress in experimental fields in 1983 was slow due to relatively long dry and very warm periods (Table 1). The assessment of disease severity (Fig. 1) indicates that the amount of disease in the mixed stand was $16 \%$ less than the arithmetic mean of the pure stands. Under low level infection stress, Kadett seems to avoid disease effectively, and the disease level in the mixtures appears to be closer to the more resistant component than the susceptible one.

Disease progress in experimental fields in 1984 was very rapid due to favourable weather conditions, frequent rains during the latter part of the growing period. Following inoculation, the development of disease on flag leaves and two uppermost leaves (Figs 2, 3) 


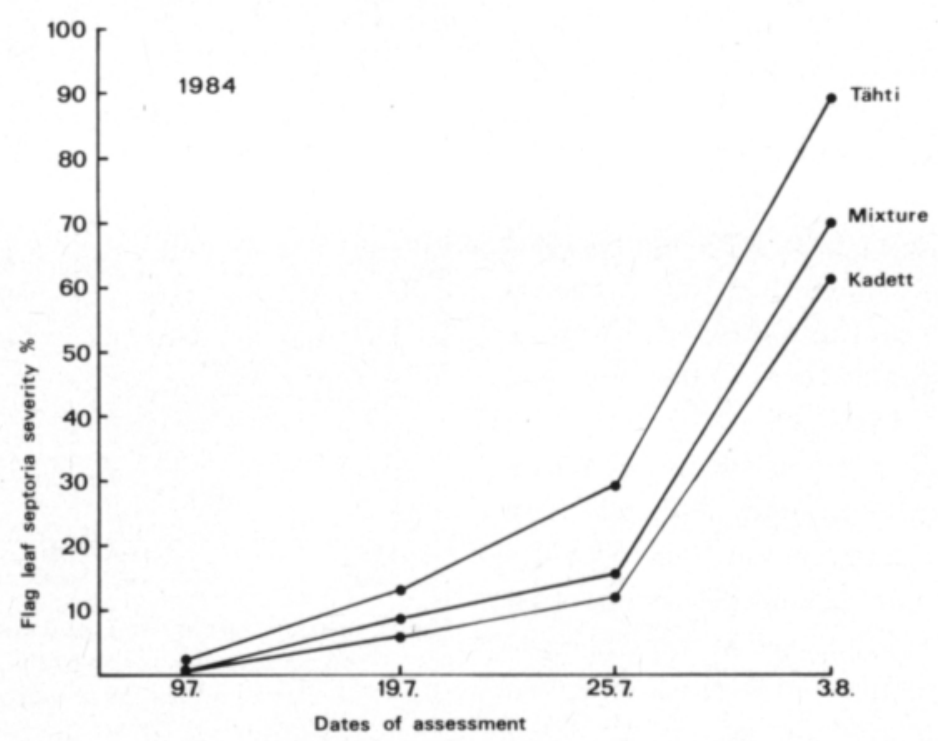

Fig. 2. Disease progress of S. nodorum on the flag leaves of spring wheat cultivars Tähti and Kadett and their binary mixture in 1984 .

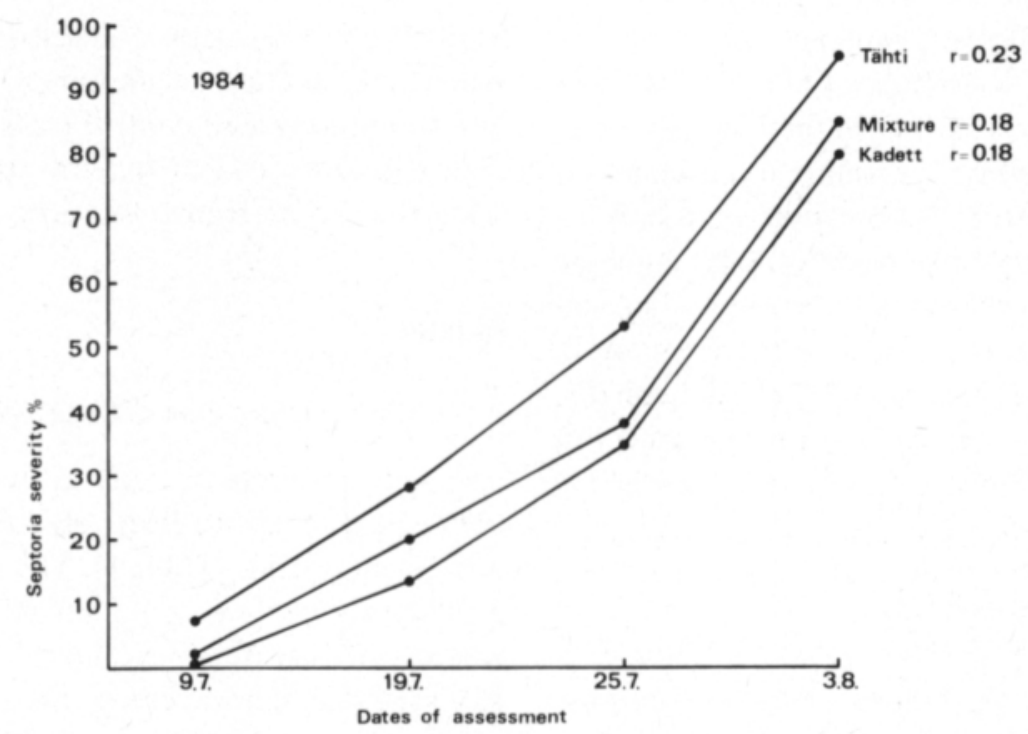

Fig. 3. Disease progress of S. nodorum (average of two upper leaves) of spring wheat cultivars Tähti and Kadett and their binary mixture in 1984. Apparent infection rates (r) were calculated on the basis of three last sampling dates and using the log e $\frac{X}{1-X}$ transformation according to ZADOKS and SCHEIN (1979).

was first slow compared with later phases. Every assessment indicated that the amount of disease was highest for Tähti and lowest for Kadett. The disease level of the mixtures appeared to fall between the two components, but was closer to the resistant cultivar, Kadett
(Fig. 4). Apparent infection rates were calculated in order to compare pathogen reproduction rates between pure stands and mixtures. The data show (Fig. 3) that the r-values for the mixture and the resistant component are identical $(r=0.18)$, while the $r$-value for Tähti 


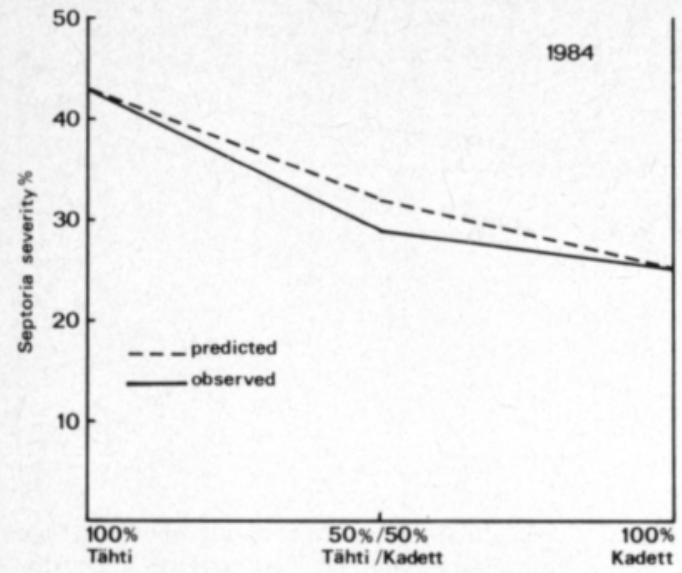

Fig. 4. Disease severity of $S$. nodorum (average of two upper leaves) of spring wheat cultivars Tăhti and Kadett and their binary mixture in 1984.

is somewhat higher $(r=0.23)$.

In 1985 the development of the disease was moderate, and the data indicate (Fig. 5) that the disease amount in mixed stands was closer to the resistant component, although the mixture benefit was small compared with the arithmetic mean of the pure stands. In all three years, $S$. nodorum was practically the only leaf pathogen present in trials, only mildew was occasionally seen.

\section{The ability of mixtures to buffer yield loss}

Disease induced yield reduction in 1983 was very small and statistically insignificant, $4.3 \%$ for Tähti, $4.4 \%$ for Kadett, and only $0.5 \%$ for the mixture (Fig. 6). The data clearly show that under low infection conditions the mixture appears to buffer against yield reduction caused by $S$. nodorum.

In 1984 , the infection by $S$. nodorum was heavy and caused statistically significant yield reductions, $35 \%$ for Tähti, $27 \%$ for Kadett, and $31 \%$ for the mixture (Fig. 7). The data show that the mixture can only slightly buffer high yield reduction. In 1984 the infection caused high and statistically significant reductions in grain weight, $21 \%$ for Tähti, $20 \%$ for Kadett, and $18 \%$ for the mixture (Fig. 8). In this case, the grain weight of the mixture

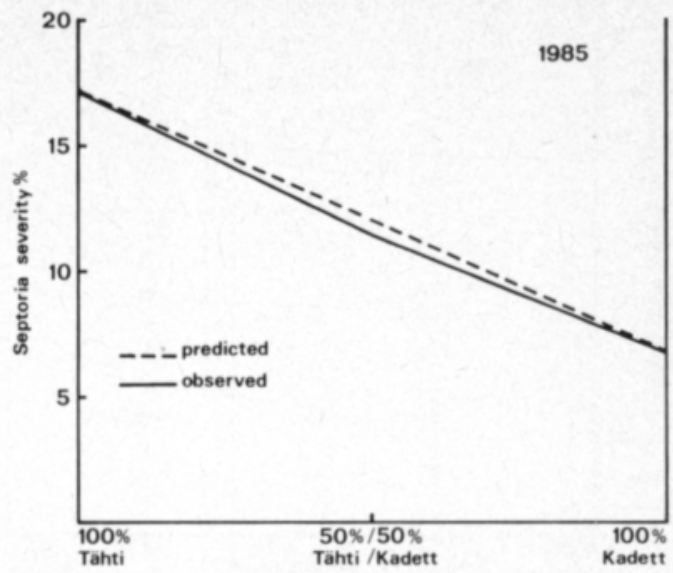

Fig. 5. Disease severity of $S$. nodorum (average of two upper leaves) of spring wheat cultivars Tähti and Kadett and their binary mixture in 1985.

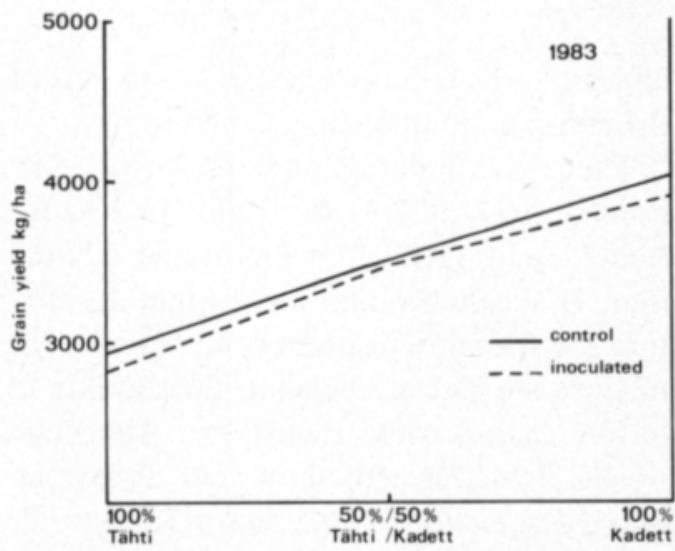

Fig. 6. The data of grain yield of spring wheat cultivars Tähti and Kadett and their mixture under disease induced stress compared with the control in 1983.

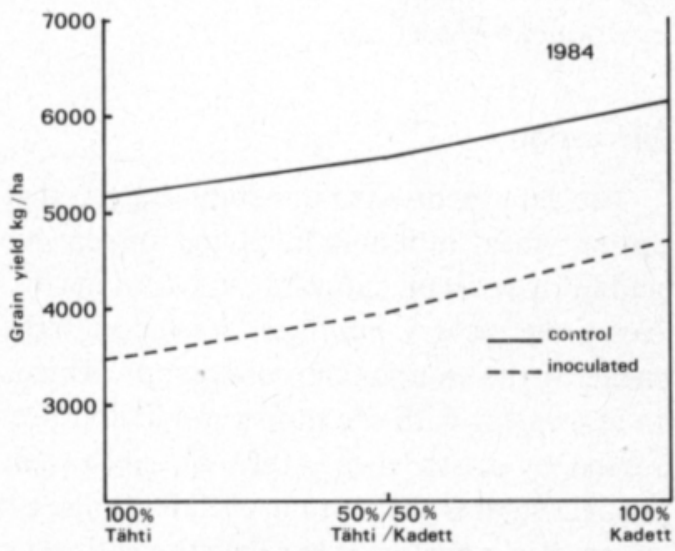

Fig. 7. The data of grain yield of spring wheat cultivars Tăhti and Kadett and their mixture under heavy disease induced stress compared with the control in 1984. 


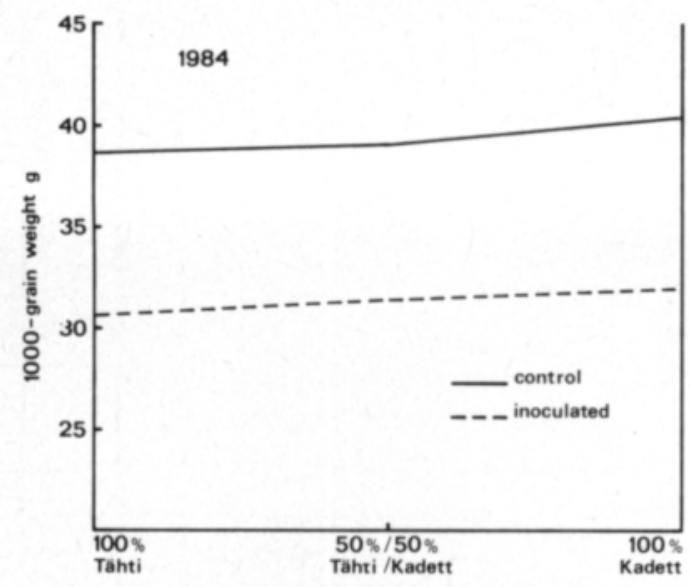

Fig. 8. Effects of $S$. nodorum on the grain weight of spring wheat cultivars Tăhti and Kadett and their mixture in relation to uninoculated controls in 1984.

appears to be reduced even less than that of the resistant component of the mixture.

The disease induced moderate yield reductions in 1985, $16.7 \%$ for Tähti, $13.7 \%$ for Kadett, and $12.1-13.9 \%$ for the mixture (Fig. 9). Again the data suggest that the mixture and the more resistant component of the mixture are rather similar in their ability to buffer against yield reductions. The grain weight data (Fig. 10) show that disease induced a reduction of $10.5 \%$ for Tähti, while the grain weight of Kadett was reduced only by $4.5 \%$ and that of the mixture by $3.7-$ $6.3 \%$. This supports the idea that mixtures can buffer disease induced yield and yield component reductions.

\section{Discussion}

The data reported in this study suggest that spring wheat mixtures involving susceptible and fairly resistant cultivars can retard the disease progress of $S$. nodorum in relation to the mean of the component pure stands. This is in agreement with the model prediction presented by JEGER et al. (1981 a), since their model suggests that the unspecialized disease progress in a mixture is less than the arithmetic mean of the pure components. JEGER et al. (1981 b) also provided experimental evidence for their model, when they found that mix-

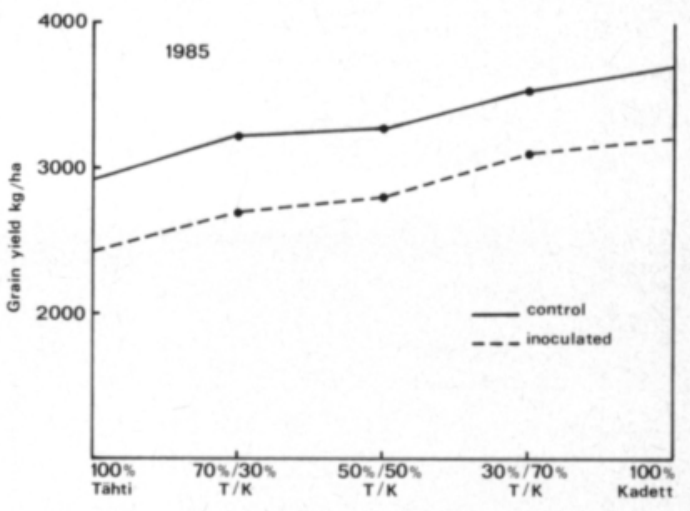

Fig. 9. The data of grain yield of spring wheat cultivars Tähti and Kadett and their mixtures under disease induced stress compared with the control in 1985 .

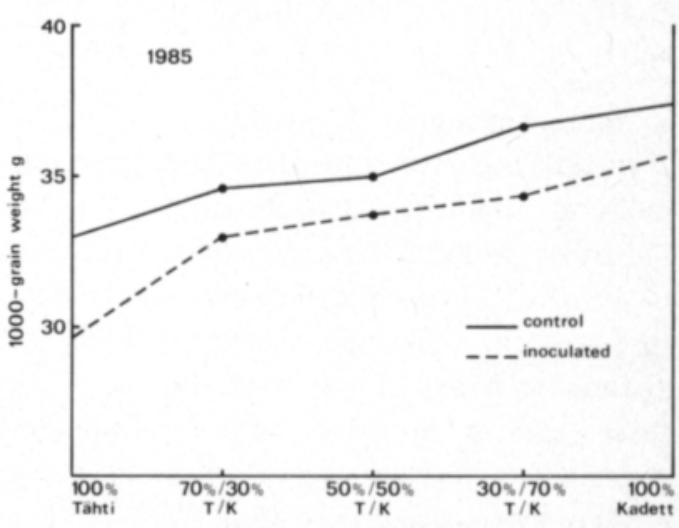

Fig. 10. Effects of $S$. nodorum on the grain weight of spring wheat cultivars Tähti and Kadett and their mixtures in relation to uninoculated controls in 1985.

tures of two cultivars differing in their partial resistance to $S$. nodorum can retard disease progress to such an extent that the presence of only $25 \%$ of the more resistant cultivar reduces disease to approximately the amount in the more resistant pure stand.

Disease progress in this experiment varied in three years. In 1983, the infection level was low, and $S$. nodorum progressed slowly from lower to upper leaves due to unfavourable dry weather. Under low infection conditions, however, the mixture benefit was clear, and the amount of disease in mixtures was substantially less than the expected mean of the component pure stands. 
In 1984, the latter part of the growing season was rainy, and following inoculation subsequent disease progress was rapid. The overall disease level was high, and even moderately resistant Kadett was rather badly diseased (KarJalainen et al. 1983). However, under heavy infection conditions the disease progress in mixtures seemed to be less than the expected mean of component pure stands. The data from experiments in 1985 contribute to the previous observations, although in this case the mixture benefit was not as high as in 1984 .

Extensive experiments on variety mixtures and the way they affect the disease progress of race-specialized pathogens have been carried out (WOLFE and BARRETT 1980, FrIED et al. 1981, MunK 1983). However, only limited data are available on the effects of mixtures against pathogens not specialized to cultivars. BRÖNNIMANN and Fossati (1976) studied mutant lines of cultivar Zenith in mixtures and found that mixtures reduced the disease development and consequent yield reduction caused by $S$. nodorum. Significant disease protection was also found by AYANRU and BRownING (1977) studying the disease epidemics of Victoria blight in heterogeneous oat populations, as well as by GROMMER and ROY (1966) examining the brown spot disease caused by Helminthosporium oryzae on intervarietal mixtures of rice. Limited data also suggest (CLARK 1980) that such interspecific mixtures as oats and barley can retard the progress of the disease caused by unspecialized Bipolaris sorokiniana. Although the data sofar are not extensive, it seems evident that cultivar mixtures can provide a practical means for the control of non-specialized pathogens.

The reason why mixtures can retard disease development is not well understood. It has been proposed (BURDON 1978) that in a pure stand of plants having uniform susceptibility to a particular pathogen, the replacement of a proportion of these plants by resistant ones reduces the amount of inoculum available for subsequent dispersal within the stand. In addition, the replacement of susceptible plants by resistant ones results in a decline in the density of the remaining susceptible plants thus increasing the average distance that inoculum has to travel between one susceptible plant and another. Consequently, the increased distance often means a reduced probability of the spread of inoculum. Other factors, such as induced resistance (JOHNSON and ALLEN 1975) have been suggested, and recent experiments on barley mixtures and powdery mildew (CHIN et al. 1984, Wolfe 1985) confirm the role of induced resistance as a factor influencing the disease development in mixtures.

In the case of $S$. nodorum and wheat mixtures, it is probable that the reduction in the proportion of susceptible tissue and the subsequent reduction in the probability of inoculum spread may play an important role in retarding epidemic development. In addition, it is apparent that crop morphological traits such as leaf angle, leaf form, distance between different leaves, and some other factors affecting microclimatic conditions may play some role in regulating the force of escape mechanisms. It is widely known (e.g. Eyal 1981) that escape mechanisms are among the important basic factors concerning the disease resistance of wheat to $S$. nodorum. $S$. nodorum spreads from lower parts of the canopy by step-wise movement to the upper leaves, and the speed of the disease progress is greatly dependent on humid conditions inside the canopy (Scharen 1964). Consequently, any crop traits that reduce the humidity in the canopy might have some important consequences for disease development.

The yield data of the present study indicate that disease induced yield reduction was quite different in three years. In 1983, the yield reduction caused by $S$. nodorum was small and in 1985 moderate, while in 1984 the crop losses were very serious as a consequence of heavy disease pressure. The grain yield reduction was obviously mainly due to the overall reduction in photosynthetic leaf area. It was observed in 1984 and 1985 that $S$. nodorum clearly shortened the duration of green leaf area by 
destroying plants leaf by leaf. Consequently, infection greatly reduced grain weight, but grain number per ear was also affected.

The data from 1983 and 1985 experiments provide evidence that mixtures can prevent disease induced yield loss to a large extent under low or moderate infection conditions, since both grain yield and grain weight of the mixture were less affected by the disease than the pure components. However, in 1984 the infection was severe and caused high losses, and the mixtures did not seem to prevent yield losses effectively. Hence, although mixtures appear to buffer disease development substantially, it is not always obvious that comparable yield advantages will be achieved. This controversy between disease data and yield measurements has been a well-known problem for a long time in mixture trials (SUNESON 1949, PARLeVliet 1979). Jeger et al. (1981 b) have pointed out that great care must be taken before ascribing any yield benefits observed in mixtures to any disease reduction also observed.

The apparently low yield benefits for mixtures in 1984 compared with the observed disease reduction may be the outcome of several reasons. First, it may partly be due to the small plot size used in this experiment, as it is known that mixture benefit is best obtained in large plot yield trials. Another explanation for the low yield benefit in relation to the significant disease reduction may be the observation (Scharen and TAYlor 1968, OBSt 1977) that the ability of $S$. nodorum to reduce grain

\section{References}

Adams, M. W., Ellingboe, A. H. \& Rossman, E. C. 1971. Biological uniformity and disease epidemics. BioScience 21: 1067-1070.

Ayanru, D. K. G. \& Browning, J. A. 1977. Effect of heterogeneous oat populations on the epiphytotic development of Victoria blight. New Phytol. 79: $613-623$.

Borlaug, N. E. 1958. The use of multilineal or composite varieties to control air-borne epidemic disease of self-pollinated crop plants. Proc. 1st Int. Wheat yield is not always correlated with observed disease symptoms. The basic reason for this is not well understood, but it may be connected with the toxin sensitivity of the host, as it is known (Bousquet et al. 1980) that $S$. nodorum is capable of producing a toxin causing physiological alterations in host metabolism.

The present investigation confirms the theoretical and limited experimental analyses (BRÖNnimann and Fossati 1976, Jeger et al. $1981 \mathrm{a}, \mathrm{b})$ that mixing cultivars differing in their resistance to $S$. nodorum can be one alternative to control disease epidemics caused by this pathogen. However, this study also suggests that despite the apparent retardment of disease progress, the yield benefit of mixtures over pure lines does not always seem to be remarkable. It is also probable that highyielding cultivars, such as Kadett, with a moderate level of resistance can produce yields much higher compared with those of mixtures. However, extensive studies are needed to clarify whether mixtures can stabilize the yield performance of spring wheat in Finnish marginal growing areas. In order to find answers to such questions, cultivars differing in their reaction to drought, rate of early growth, resistance to powdery mildew and $S$. nodorum and many other characters probably affecting the stability of yield (e.g. Mukula et al. 1977) must be selected for mixtures. Furthermore, in order to produce relevant practical information for wheat farmers, large plot trials in different areas for several years are required.

Genet. Symp., University of Manitoba, Winnipeg, p. 12-26.

Bousquet, J. F., De Franqueville, H. B., Kollman, A. \& FrITZ, R. 1980. The action of Septorin, phytotoxin synthesised by Septoria nodorum on oxidative phosphorylation in mitochondria isolated from wheat coleoptiles. Can J. Bot. 58: 2575-2580.

Brónnimann, A. \& Fossati, A. 1976. Ertragsstruktur und Reaktion auf Befall durch Septoria nodorum Berk. von Halmlange-Mutaten der Weizensorte Zenith bei Anbau im Gemisch. Schweizerisch Landw. Forschung 15: 463-472. 
Browning, J. A. \& FreY, K. J., 1969. Multiline cultivars as a means of disease control. Ann. Rev. Phytopathol. 7: 355-382.

-, Frey, K. J., McDaniel, M. E., Simons, M. D. \& WAHL, I. 1979. The bio-logic of using multilines to buffer pathogen populations and prevent disease loss. Indian J. Genet. \& Plant Breeding 39: 3-9.

Burdon, J. J. 1978. Mechanisms of disease control in heterogeneous plant populations - an ecologist's view. Plant disease epidemiology, ed. Scott, P. R. \& Bainbridge, A. p. 193-200. Blackwell Scientific Publications, Oxford.

Chin, K. M., Wolfe, M. S. \& Minchin, P. N. 1984. Host-mediated interactions between pathogen genotypes. Plant Path. 33: 161-172.

Cl.ark, R. V. 1980. Comparison of spot blotch severity in barley grown in pure stands and in mixtures with oats. Can. J. Plant Pathol. 2: 37-38.

Clay, R. E. \& Allard, R. W. 1969. A comparison of the performance of homogeneous and heterogeneous barley populations. Crop Sci. 9: 407-412.

DAY, P. R. 1973. Genetic variability of crops. Ann. Rev. Phytopathol. 11: 292-312.

EyAL, Z. 1981. Integrated control of Septoria disease of wheat. Plant Dis. 65: 763-768.

Frey, K. J., Browning, J. A. \& Simons, M. D. 1977. Management systems for host genes to control disease loss. Ann. N. Y. Acad. Sci. 287: 255-274.

- \& Maldonado, V. 1967. Relative productivity of homogeneous and heterogeneous oat cultivars in optimum and suboptimum environments. Crop Sci. 7: 532-535.

Fried, P. M., MacKenzie, D. R. \& Nelson, R. R. 1979. Disease progress curves of Erysiphe graminis f. sp. tritici on Chancellor wheat and four multilines. Phytopath. Z. 95 : $151-166$.

-, MacKenzie, D. R. \& Nelson, R. R. 1981. Yield loss caused by Erysiphe graminis f. sp. tritici on single culms of 'Chancellor' wheat and four multilines. Z. Pflkrkh. Pflschutz. 88: 256-264.

Grommer, G. \& Roy, S. K. 1966. Intervarietal mixtures of rice and incidence of brown spot disease (Helminthosporium oryzae Breda de Haan). Nature 209: 1265-1267.

Jeger, M. J., Griffiths, E. \& Jones, D. G. 1981 a. Disease progress of non-specialised fungal pathogens in intraspecific mixed stands of cereal cultivars. I. Models. Ann. Appl. Biol 98: 187-198.

-, Jones, D. G. \& Griffiths, E. 1981 b. Disease progress of non-specialised fungal pathogens in intraspecific mixed stands of cereal cultivars. II. Field experiments. Ann. Appl. Biol. 98: 199-210.

JENSEN, N. F. 1952. Intra-varietal diversification in oat breeding. Agron. J. 44: 30-34.

Johnson, R. \& Allen, D. J. 1975. Induced resistance to rust diseases and its possible role in the resistance of multiline varieties. Ann. Appl. Biol. 80: 359-363.

KARJALAINEN, R. 1984. Evaluation of detached seedling leaves for use in screening spring wheat cultivars to Septoria nodorum Berk. Acta Agric. Scand. 34: 386-390.

- 1985. Host - pathogen interaction between spring wheat and Septoria nodorum with reference to resistance breeding. J. Agric. Sci. Finl. 57: 1-66.

—, Laitinen, A. \& JuUtı, T. 1983. Susceptibility of spring wheat cultivars and breeding lines to Septoria nodorum Berk. J. Scient. Agric. Soc. Finl. 55: 315-332.

King, J. E., CoOK, R. J. \& Melville, S. C. 1983. A review of Septoria diseases of wheat and barley. Ann. Appl. Biol. 103: 345-373.

Marshall, D. R. 1977. The advantages and hazards of genetic homogeneity. Ann. N. Y. Acad. Sci. 287: 1-20.

— \& Brown, A. D. H. 1973. Stability of performance of mixtures and multilines. Euphytica 22: 405-412.

Mukula, J., Rantanen, O. \& LallukKa, U. 1977. Kevătvehnăn viljelyvarmuus Suomessa 1950-1976. MTTK, Kasvinviljelylaitoksen tiedote $8: 1-72$.

Munk, L. 1983. Response of a powdery mildew population to a barley variety mixture. Durable resistance in crops, ed. Lamberti, F., Waller, J. M. \& Van der Graaff, N. A. p. 105-107. Plenum Press, New York.

Oвsт, A. 1977. Untersuchungen zur Epidemiologie, Schadwirkung und Prognose der Spelzenbräune (Septoria nodorum) des Weizens. Bayerisches Landw. Jahrb. 1: 72-117.

PARleVliet, J. E. 1979. The multiline approach in cereals to rusts: aspects, problems and possibilities. Indian J. Genet. \& Plant Breeding 39: 22-29.

Pfahler, P. L. \& Linskens, H. F. 1979. Yield stability and population diversity in oats (Avena spp.). Theor. Appl. Genet. 54: 1-5.

Rajeswara Rao, B. R. \& Prasad, R. 1982. Productivity and nutrient uptake by two spring wheat cultivars in pure and mixed stands. Z. Acker- und Pflanzenbau 151: 235-244.

- \& PrASAD, R. 1984. Intergenotypic competition in mixed stands of spring wheat genotypes. Euphytica 33: 241-247.

SCharen, A. L. 1964. Environmental influences on development of glume blotch in wheat. Phytopath. 54: 300-304.

— \& TAYLOR, J. M. 1968. $\mathrm{CO}_{2}$ assimilation and yield of little club wheat infected by Septoria nodorum. Phytopath. 58: 447-451.

Shorter, R. \& Frey, K. J. 1979. Relative yields of mixtures and monocultures of oat genotypes. Crop Sci. 19: $548-553$.

SimmondS, N. W. 1962. Variability in crop plants, its use and conservation. Biol. Rev. 37: 442-465.

SunESON, C. A. 1949. Survival of four barley varieties in a mixture. Agron. J. 41: 459-461.

- 1960. Genetic diversity - a protection against plant diseases and insects. Agron. J. 52: 319-321.

TrenBATH, B. R. 1974. Biomass productivity of mixtures. 
Adv. Agron. 26: 177-210.

WoLfE, M. S. 1985. The current status and prospects of multiline cultivars and variety mixtures for disease resistance. Ann. Rev. Phytopathol. 23: 251-273.

- \& Barrett, J. A. 1980. Can we lead the pathogen astray? Plant Dis. 64: 148-155.

- BARRETT, J. A. 1982. The agricultural value of variety mixtures. Proc. 4th Barley Genet. Symp., Univ. of Edinburgh, Edinburgh, p. 435-440.

ZADOKS, J. C. \& SCHEIN, R. D. 1979. Epidemiology and plant disease management. 427 p. Oxford University Press, Oxford.

Ms received

\section{SELOSTUS}

\section{Lajikeseosten viljelyarvo kevätvehnän tuotannossa: seosten kyky vähentää Septoria-taudin aiheuttamia satotappioita}

\section{Reijo Karjalainen}

Helsingin yliopiston kasvipatologian laitos ja kasvinjalostustieteen laitos 00710 Helsinki

Helsingin yliopiston Viikin koetilalla selvitettiin vuosina 1983-1985 kevătvehnăn lajikeseosten vaikutusta Septoria-taudin leviämiseen ja sen aiheuttamiin satotappioihin. Koeruudut infektoitiin keinotekoisesti Septoria nodorum -sienellä, ja taudin aiheuttamia satotappioita verrattiin käsittelemăttőmiin koeruutuihin. Koelajikkeina olivat taudinaltis Tähti sekă tautia kohtalaisesti kestävă Kadett.

Tulokset osoittivat, ettă taudin lisäăntymisnopeus la- jikeseoksessa văheni kestävămmăn Kadett-lajikkeen tasolle. Taudin mäără seoksessa oli lăhempănă kestăvămpaaă lajiketta ja aina văhäisempi kuin seoksen komponenttien aritmeettinen keskiarvo. Tehokkaimmin lajikeseokset pystyivăt korvaamaan kohtalaisen voimakkaan Septoria-taudin aiheuttamia satotappioita mutta voimakkaan saastunnan aiheuttamaa satotappiota ne eivăt sanottavasti estäneet. Parhaan sadon tuotti Kadett-lajike voimakkaankin tauti-infektion jälkeen. 